\title{
GREEN ACCOUNTING : PEMAHAMAN DAN KEPEDULIAN DALAM PENERAPAN (Studi Kasus Pada Pabrik Kecap Lele di Kabupaten Pati)
}

\author{
Yunu Kurnelia Yuliana ${ }^{1}$ \\ Ardiani Ika Sulistyawati ${ }^{2}$ \\ yunuky17@gmail.com ${ }^{1}$ \\ ardiani@usm.ac.id ${ }^{2}$
}

Fakultas Ekonomi Universitas Semarang

Diterima : November 2020, Disetujui : Desember 2020, Dipublikasikan: Januari 2021

\begin{abstract}
This research was conducted at Lele Soy-sauce Factory located in Pati District, Central Java. This reaserch aims to find out if green accounting is already applied in the Lele Soy-sauce Factory and is already doing green cost for the recording of green accounting that has be done. This reaserch uses qualitative descriptive methods, with the probles of case studies. Researches use observation techniques, interviews, as well as documentation on research objects. In addition, researchers also choose the informant according to what the researchers would ask and with the informant that really understands about the Lele Soy-sauce Factory. The informant interviewed there are 3, namely: leaders, cooks, and also waste-processing employees from Lele Soy-Sauce Factory. From the research result can be known that in the Lele Soy-sauce Factory has done green accounting for factory waste to be released into rivers and trenches in a factory. But it has not done green cost for the issurance of green accounting funds that have been implemented.
\end{abstract}

Keywords : green accounting, green cost, UMKM Kecap.

\begin{abstract}
ABSTRAK
Penelitian ini dilakukan di Pabrik Kecap Lele yang terletak di Kabupaten Pati, Jawa Tengah. Penelitian ini bertujuan untuk mengetahui apakah green accounting sudah diterapkan di Pabrik Kecap Lele dan sudah melakukan green cost untuk pencatatan green accounting yang telah dilakukan. Penelitian ini menggunakan metode deskriptif kualitatif dengan berpedoman pada studi kasus. Peneliti menggunakan teknik observasi, wawancara, serta dokumentasi terhadap objek penelitian. Selain itu peneliti juga memilih informan sesuai dengan apa yang peneliti tanyakan dan dengan informan yang benar-benar paham tentang Pabrik Kecap Lele. Informan yang diwawancarai ada 3, yaitu: pimpinan, juru masak, serta karyawan pengolah sampah dari Pabrik Kecap Lele. Dari hasil penelitian dapat diketahui bahwa di Pabrik Kecap Lele telah dilakukan green accounting untuk limbah pabrik yang akan dibuang ke sungai dan parit di pabrik. Namun belum dilakukan green cost untuk penjaminan dana green accounting yang telah dilaksanakan.
\end{abstract}

Kata kunci: green accounting, green cost, UMKM Kecap.

\section{PENDAHULUAN}

Di Indonesia memiliki banyak sektor yang menjadi pilar penyangga perekonomian negara. Salah satunya adalah sektor industri, yang mana dari sektor ini terdapat sektor UMKM (Usaha Mikro, Kecil, dan Menengah). Industri adalah kegiatan ekonomi yang 
mengelola bahan mentah, bahan baku, barang setengah jadi, dan atau barang jadi menjadi barang dengan nilai yang lebih tinggi untuk penggunaanya termasuk kegiatan rancang bangun dan perekayasaan industri (UU Perindustrian No. 5 tahun 1984).

UMKM sendiri merupakan langkah yang strategis dalam meningkatkan dasar kehidupan rakyat sebagai penyedia lapangan pekerjaan, mengurangi kesenjangan sosial, dan kemiskinan. Akan tetapi, dengan adanya UMKM ini juga mempunyai dampak buruk bagi lingkungan apabila tidak ditangani dengan baik. Dampak tersebut mengakibatkan penurunan kualitas lingkungan berupa pencemaran udara, tanah, dan air.

Kesadaran dari masyarakat terhadap lingkungannya memberikan ide untuk mengadakan gerakan peduli lingkungan (green movement) sebagai bentuk konsekuensi dari industri yang bersangkutan. Kepedulian lingkungan inilah yang mendasari munculnya akuntansi hijau (green accounting). Green accounting adalah proses akuntansi yang mengintegrasikan pengakuan, pengukuran nilai, pencatatan, peringkasan, dan pelaporan informasi keuangan, sosial dan lingkungan secara terpadu dalam satu paket pelaporan akuntansi, yang berguna bagi para pemakai dalam penelitian dan pengambilan keputusan ekonomi dan non - ekonomi. Namun secara khusus green accounting membahas tentang identifikasi, pengukuran dan alokasi biaya lingkungan, mengintegrasikan biaya lingkungan ke dalam bisnis dan mengidentifikasi kewajiban terhadap lingkungan. Tujuan akuntansi lingkungan adalah memberikan informasi mengenai kinerja operasional perusahaan yang berbasis perlindungan dan kepedulian terhadap lingkungan, sehingga perusahaan tidak bisa seenaknya untuk mengolah sumber daya tanpa memerhatikan dampaknya terhadap masyarakat.

Salah satu UMKM pendamping makanan yang cukup terkenal yang terletak di Jalan Pati - Juwana KM 3, Kabupaten Pati, Jawa Tengah adalah Pabrik Kecap Cap Ikan Lele. Limbah yang dihasilkan dari pengolahan bahan - bahan kecap ini berpotensi menyebabkan pencemaran lingkungan. Kualitas limbah yang dihasilkan sangat jauh memenuhi persyaratan yang berkualitas.

Menurut Susilowarno (2007) dikutip dari Pengertian Limbah Menurut Ahli, limbah adalah sisa atau hasil sampingan dari kegiatan manusia untuk memenuhi kebutuhan hidupnya. Pembuangan limbah yang tidak diolah terlebih dahulu sebelum dibuang ke dalam lingkungan menyebabkan polusi. Dampak negatif limbah tersebut dapat menimbulkan masalah dalam penanganannya karena mengandung sejumlah besar karbohidrat, protein, lemak, garam garam. Pencemaran lingkungan ini jika diteruskan maka akan mengganggu ekosistem di bumi. Seperti mengganggu ekosistem sungai dan menimbulkan pencemaran udara yaitu dengan terciumnya aroma busuk disekitar pabrik.

Akuntansi merupakan suatu ilmu yang dipengaruhi dan mempengaruhi lingkungan sekitarnya. Akuntansi lingkungan didefiniskan sebagai pencegahan, pengurangan dan atau penghindaran dampak terhadap lingkungan bergerak dari beberapa kesempatan, dimulai dari perbaikan kembali kejadian-kejadian yang menimbukan bencana atas kegiatan-kegiatan tersebut. Untuk itu ada istilah Green Accounting dimana hal ini membahas mengenai apa hal yang dapat membuat dampak negatif bagi lingkungan sekitar, bagaimana penanganannya, pencatatan dalam laporan keuangan secara kronologis dan juga penerapannya di kehidupan sehari - hari.

Dalam Green Accounting mengumpulkan biaya, produksi, persediaan, dan biaya limbah dan kinerja untuk perencanaan, pengembangan, evaluasi, dan kontrol atas keputusan - 
keputusan bisnis. Tujuannya untuk meningkatkan efesiensi pengelolaan lingkungan dengan melakukan penilaian kegiatan lingkungan dari sudut pandang biaya (environmental cost) dan manfaat atau efek, serta menghasilkan efek perlindungan lingkungan. Green Accounting (akuntansi hijau) atau Environmental Accounting (akuntansi lingkungan) adalah penggabungan informasi manfaat dan biaya lingkungan ke dalam macam - macam praktik akuntansi dam penggabungan biaya lingkungan ke dalam keputusan bisnis. Akuntansi lingkungan merupakan sarana untuk melaporkan operasional suatu lembaga yang dikaitkan dengan lingkungan.

Dalam menjalankan usahanya, UMKM diwajibkan untuk memahami dan menerapkan konsep green accounting, dikarenakan UMKM sendiri selain sebagai penyumbang perekonomian juga berperan dalam menghasilkan limbah yang dapat mencemari lingkungan. Untuk itu diperlukan pengelolaan limbah dengan baik agar tidak mencemari lingkungan. Dengan adanya pengelolaan limbah tersebut dibutuhkan biaya untuk mengoperasionalkannya, biaya tersebut memerlukan biaya tersendiri yang disebut biaya lingkungan (green cost). Biaya lingkungan merupakan dampak yang timbul dari sisi keuangan dan non - keuangan yang wajib dipikul sebagai akibat dari suatu usaha yang dilakukan yang berkaitan dengan lingkungan. Biaya lingkungan yang terjadi di perusahaan termasuk salah satu biaya overhead pabrik yang sulit diidentifikasi secara langsung, karena biaya tersebut tersembunyi di dalam pusat biaya, tidak ada bukti pencatatan yang jelas mengenai biaya lingkungan.

\section{TINJAUAN PUSTAKA}

\section{Usaha Mikro, Kecil dan Menengah}

Dalam perekonomian Indonesia, Usaha Mikro, Kecil, dan Menengah (UMKM) adalah kelompok usaha yang memiliki jumlah paling besar. Kelompok ini terbukti tahan dalam berbagai macam goncangan krisis ekonomi. Berdasarkan Undang - undang No. 20 Tahun 2008 tentang Usaha Mikro, Kecil, dan Menengah (UMKM) ada beberapa kriteria yang dipergunakan untuk mendefinisikan pengertian dan kriteria dan kriteria UMKM. Pengertian UMKM tersebut adalah :

a) Usaha Mikro

Usaha produktif milih perseorangan dan/atau badan usaha perseorangan yang memenuhi kriteria usaha mikro yang diatur dalam undang - undang. Usaha ini memiliki kekayaan bersih Rp. 50.000.000,- dan tidak termasuk bangunan dan tanah tempat usaha. Hasil dari usaha mikro setiap tahunnya Rp. 300.000.000,-.

b) Usaha Kecil

Usaha ekonomi produktif yang berdiri sendiri dan dilakukan oleh perseorangan atau badan usaha yang bukan merupakan anak perusahaan yang dimiliki, dikuasai, atau menjadi bagian baik langsung ataupun tidak langsung dari usaha menengah atau usaha besar yang memenuhi kriteria usaha kecil yang diatur dalam undang - undang. Usaha ini memiliki kekayaan bersih Rp. 50.000.000,- dengan hasil maksimal yang dibutuhkannya mencapai Rp. 500.000.000,-. Hasil penjualan bisnis setiap tahunnya antara Rp. 300.000.000,- sampai dengan Rp. 2.500.000.000,-.

c) Usaha Menengah

Usaha ekonomi produktif yang berdiri sendiri, yang dilakukan oleh perseorangan atau badan usaha yang bukan merupakan anak perusahaan atau cabang perusahaan yang 
dimiliki, dikuasai, atau menjadi bagian baik langsung maupun tidak langsung dengan usaha kecil atau usaha besar dengan jumlah kekayaan bersih atau hasil penjualan tahunan yang diatur di dalam undang - undang. Sebagai bisnis besar kriteria kekayaan bersih yang dimiliki pemilik usaha mencapai lebih dari Rp. 500.000.000,- sampai dengan Rp. 10.000.000.000,- dan tidak termasuk bangunan dan tanah tempat usaha. Hasil penjualan setiap tahunnya mencapai Rp. 2.500.000.000,- menapai Rp. 500.000.000.000,-.

Berdasarkan perkembangannya, UMKM di Indonesia dapat dibedakan dalam 4 kriteria, yaitu:

1) Livelihood Activities, yaitu UMKM yang dimanfaatkan sebagai kesempatan kerja dan mencari nafkah, yang lebih umum dikenal sebagai sektor informal.

2) Micro Enterprise, yaitu UMKM yang mempunyai sifat pengrajin namun belum mempunyai sifat kewirausahaan.

3) Small Dynamic Enterprise, yaitu UMKM yang telah memiliki jiwa entrepreneurship dan mampu menerima pekerjaan subkontrak dan ekspor.

4) Fast Moving Enterprise, yaitu UMKM yang mempunyai jiwa entrepreneurship dan akan bertransformasi menjadi sebuah usaha besar.

Berikut yang merupakan ciri - ciri dari Usaha Mikro, Kecil, dan Menengah (UMKM) :

a) Jenis atau komoditi barang yang ada pada usahanya tidak tetap atau bisa berganti sewaktu - waktu.

b) Tempat menjalankan usahanya bisa berpindah sewaktu - waktu.

c) Usahanya belum menerapkan administrasi, bahkan keuangan pribadi dan keuangan usaha masih disatukan.

d) Sumber Daya Manusia (SDM) di dalamnya belum punya jiwa wirausaha yang mumpuni.

e) Biasanya tingkat pendidikan SDM nya masih rendah.

f) Bisanya pelaku UMKM belum memiliki akses perbankan, namun sebagian telah memiliki akses ke lembaga keuangan non - perbankan.

g) Pada umumnya belum punya surat ijin usaha atau legalitas, termasuk NPWP.

\section{Pemberdayaan UMKM}

Memberdayakan mengandung arti melindungi. Dalam proses pemberdayaan, harus dicegah yang lemah menjadi bertambah lemah dalam menghadapi yang kuat. Pemberdayaan masyarakat lokal dan jaminan hak - hak masyarakat disekitar daerah operasional perusahaan merupakan kewajiban yang harus dilaksanakan. Pemberdayaan masyarakat yang sanga efektif membuat masyarakat menjadi berdaya guna dan adaptif terhadap perubahan yang terjadi di lingkungannya. Pemberdayaan adalah merupakan suatu upaya untuk membangun masyarakat dengan mendorong, memotivasi, dan membangkitkan kesadaran akan potensi yang dimilikinya dan berupaya untuk mengembangkannya (Syarif, 2001 dalam Sukarno, 2008. Dikutip dari Jurnal Diana Puspitasari).

Pemberdayaan masyarakat sendiri memiliki arti proses pembangunan sumber daya manusia atau masyarakat itu sendiri dalam bentuk penggalian kemampuan pribadi, kreatifitas, kompetensi, dan gaya pikir serta tindakan yang lebih baik dari sebelumnya. Pemberdayaan masyarakat adalah hal yang penting dan wajib dilakukan untuk meningkatkan pertumbuhan ekonomi dan teknologi yang pesat saat ini yang akan memengaruhi perkembangan setiap 
individu dalam memenuhi kebutuhan hidup. Tujuan dari pemberdayaan masyarakat ini adalah

a) Melahirkan individu - individu yang mandiri dalam masyarakat.

b) Menciptakan lingkungan yang memiliki etos kerja yang baik sehingga mampu menciptakan kondisi kerja yang sehat dan saling menguntungkan.

c) Menciptakan masyarakat yang memiliki kesadaran tinggi akan potensi diri dan lingkungan di sekitarnya dengan baik.

d) Melatih dan memampukan masyarakat untuk melakukan perencanaan dan pertanggung jawaban atas tindakan mereka dalam memenuhi kebutuhan hidup.

e) Menambah kemampuan berpikir dan bernegoisasi atau mencari solusi terhadap permasalahan - permasalahan yang mungkin ditemui dalam lingkungannya.

f) Memperkecil kemiskinan dengan cara meningkatkan potensi dan kemampuan dasar yang dimiliki masyarakat.

Pemberdayaan Usaha Mikro, Kecil, dan Menengah (UMKM) merupakan langkah yang strategis dalam meningkatkan dasar kehidupan rakyat Indonesia, khsususnya melalui penyediaan lapangan kerja dan mengurangi kesenjangan dan tingkat kemiskinan. Perkembangan peran usaha kecil dan menengah (UMKM) yang besar ditunjukkan oleh jumlah unit usaha, pengusaha, serta kontribusinya terhadap pendapatan nasional, dan penyedia lapangan kerja (Tim Kementrian Koperasi dan UKM, 2012).

\section{Green Accounting}

Akuntansi merupakan suatu ilmu yang dipengaruhi dan memengaruhi lingkungannya. Akuntansi tumbuh dan berkembang di dalam masyarakat yang juga terus berkembang. Eksistensi tidak bebas nilai terhadap perkembangan masa. Metode - metode pembukan juga terus berkembang mengikuti kompleksitas bisnis yang semakin tinggi. Ketika kepedulian terhadap lingkungan mulai mendapat perhatian masyarakat, akuntansi berbenah diri agar siap menginternalisasi berbagai eksternalitas. Maka muncul wacana akuntansi sosial dan akuntasi lingkungan yang memunculkan konsep Socio Ecomnomic Environmental Accounting (SEEC) yang merupakan penjelasan singkat pengertian Triple Bottom Line (Wiedmann dan Manfred, 2006) dimana pelaporan akuntansi ke publik tidak saja mencakup kinerja ekonomi tetapi juga kinerja lingkungan dan sosialnya (Dikutip dari Jurnal Joko Susilo).

Menurut Uno (2004) dikutip dari Jurnal Diana Puspitasari, Green Accounting (akuntansi hijau) atau Environmental Accounting (akuntansi lingkungan) adalah penggabungan informasi manfaat dan biaya lingkungan ke dalam macam - macam praktik akuntansi dam penggabungan biaya lingkungan ke dalam keputusan bisnis. Akuntansi lingkungan merupakan sarana untuk melaporkan operasional suatu lembaga yang dikaitkan dengan lingkungan. Green Accounting mengidentifikasikan, menilai, dan mengukur aspek penting dari kegiatan sosial ekonomi perusahaan dalam rangka memelihara kualitas lingkungan hidup, (Dewi, 2016. Dikutip dari Jurnal Diana Puspitasari). Tujuannya adalah memberikan informasi mengenai kinerja operasional perusahaan yang berbasis pada perlindungan dan kepedulian terhadap lingkungan, dengan cara mengidentifikasi, mengumpulkan, menghitung, dan menganalisis materi dan energi yang terkait biaya, pelaporan internal, dan menggunakan informasi tentang biaya lingkungan, menyediakan biaya - biaya lain yang terkait sehingga perusahaan tidak bisa seenaknya untuk mengolah sumber daya tanpa memperhatikan dampaknya terhadap masyarakat. 
Menurut Kwarto (2010) dikutip dari Jurnal Destiana Pentiana, beberapa petimbangan bagi perusahaaan untuk menerapkan akuntansi lingkungan sebagai bagian dari sistem akuntansi perusahaan yaitu :

(1) Memungkinkan mengurangi dan menghilangkan biaya lingkungan.

(2) Meningkatkan kinerja lingkungan perusahaan yang mungkin memliliki dampak negatif pada manusia, kesehatan, dan keberhasilan bisnis perusahaan.

(3) Diharapkan menghasilkan biaya atau harga yang lebih akurat terhadap produk dari proses lingkungan yang diinginkan dan memungkinkan untk memenuhi kebutuhan pelanggan yang mengharapkan produk atau jasa lingkungan.

\section{Peraturan Yang Terkait Dengan Green Accounting}

Dalam aturan hukum yang mengatur penerapan green accounting khusus UMKM di Indonesia saat ini belum ada, namun penerapan green accounting pada perusahaan swasta diatur dalam PP No. 47 Tahun 2012 yang merupakan tindak lanjut dari UU Perseroan Terbatas No. 40 Tahun 2007. Dalam undang - undang disebutkan bahwa setiap perseroan mempunyai tanggung jawab sosial dan lingkungan yang menjalankan usahanya di bidang yang berkaitan dengan sumber daya alam (Lindrianasari, 2007. Dikutip dari Jurnal Santi Rahma Dewi).Selain itu juga ada Undang - undang yang mendasari kewajiban dalam pengelolaan dan pelestarian lingkungan hidup, antara lain :

1) Undang - undang No. 23 Tahun 1997 tentang Pengelolaan Lingkungan Hidup.

UU ini mengatur tentang kewajiban setiap orang yang berusaha atau berkegiatan untuk menjaga, mengelola, dan memberikan informasi yang benar dan akurat mengenai lingkungan hidup. Akibat hukum juga telah ditetukan bagi pelanggaran yang menyebabkan pencemaran dan perusahaan lingkungan hidup.

2) Undang - undang No. 25 Tahun 2007 tentang Penanaman Modal.

Dalam UU ini diatur kewajiban bagi setiap penanaman modal berbentuk badan usaha atau perorangan untuk melaksanakan tanggung jawab sosial perusahaan, menjaga kelestarian lingkungan hidup dan menghormati tradisi budaya masyarakat sekitar. Pelanggaran terhadap kewajiban tersebut dapat dikenai sanksi berupa peringatan tertulis, pembatasan, pembekuan, dan pencabutan kegiatan dan/atau fasilitas penanaman modal.

3) Keputusan Ketua Badan Pengawas Pasar Modal dan Lembaga Keuangan No: KEP 134/BL/2006 tentang Kewajiban Penyampaian Laporan Tahunan bagi Emiten atau Perusahaan Publik yang mengatur mengenai kewajiban laporan tahunan yang memuat Tata Kelola Perusahaan (Coorporate Governance) harus menguraikan aktivitas dan biaya yang dikeluarkan berkaitan dengan tanggung jawab sosial perusahaan terhadap masyarakat dan lingkungan.

4) Peraturan Bank Indonesia No. 7/2/PBI/2005 tentang Penetapan Peringkat Kualitas Aktiva Bagi Bank Umum.

Dalam aturan ini aspek lingkungan menjadi salah satu syarat dalam pemberian kredit. Setiap perusahaan yang ingin mendapatkan kredit perbankan, harus mampu memperlihatkan kepeduliannya terhadap pengelolaan lingkungan. Standar pengukur kualitas limbah perusahaan yang dipakai adalah PROPER. Dengan menggunakan lima 
peringkat (hitam, merah, biru, hijau, dan emas) perusahaan akan diperingkat berdasarkan keberhasilan dalam pengelolaan limbahnya.

\section{Green Cost}

Green Cost (biaya lingkungan) merupakan dampak yang timbul dari sisi keuangan maupun non - keuangan yang harus dipikul sebagai akibat dari kegiatan yang memengaruhi kualitas lingkungan (Ikhsan, 2008. Dikutip dari Jurnal Destia Pentiana). Biaya lingkungan mencakup seluruh biaya - biaya yang paling nyata dalam mengukur ketidakpastian, pada dasarnya berhubungan dengan biaya produk, proses, sistem, atau fasilitas penting untuk mengambil keputusan manajemen yang baik. Biaya lingkungan yang terjadi di dalam perusahaan merupakan salah satu biaya overhead pabrik yang sulit diidentifikasi secara langsung, karena biaya - biaya tersebut sering kali tersembunyi dalam pusat biaya, dan tidak ada bukti pencatatan ataupun pelaporan yang jelas terkait dengan biaya lingkungan.

Aktivitas - aktivitas dalam pelaksanaan green accounting tentunya mengeluarkan biaya yang harus dibebankan oleh perusahaan yang timbul bersamaan dnegan penyedia barang dan jasa kepada konsumen. Dengan beban yang telah dialokasikan diharapkan akan membentuk lingkungan yang sehat dan terjaga kelestariannya. Kinerja lingkungan merupakan salah satu pengukuran penting dalam menunjang keberhasilan perusahaan.

Menurut Fasua (2011:1. Dikutip dari Jurnal Destia Pentiana) ada beberapa alasan yang dapat mendukung pelaksanaan akuntansi lingkungan antara lain :

a. Biaya lingkungan secara signifikan dapat dikurangi atau dihilangkan sebagai hasil dari keputusan bisnis, mulai dari perubahan dalam operasional dan pemeliharaan untuk diinvestasikan dalam proses yang berteknologi hijau serta untuk perancangan kembali produk yang dihasilkan.

b. Biaya lingkungan jika tidak mendapatkan perhatian khusus akan menjadi tidak jelas dan masuk dalam akun overhead atau bahkan akan diabaikan.

c. Banyak perusahaan telah menemukan bahwa biaya lingkungan dapat diimbangi dengan menghasilkan pendapatan melalui penjualan limbah sebagai suatu produk.

d. Pengelolaan biaya lingkungan yang lebih baik dapat menghasilkan perbaikan kinerja lingkungan dan memberikan manfaat yang signifikan bagi kesehatan manusia serta keberhasilan perusahaan.

e. Memahami biaya lingkungan dan kinerja proses dan produk dapat mendorong penetapan biaya dan harga produk lebih akurat dan dapat membantu perusahaan dalam mendesain proses produksi, barang dan jasa yang lebih ramah lingkungan.

f. Perusahaan mempunyai keunggulan kompetitif yang didapat dari proses, barang, dan jasa yang bersifat ramah lingkungan.

g. Akuntansi untuk biaya lingkungan dan kinerja lingkungan dapat mendukung perkembangan perusahaan dan operasi dari sistem menejemen lingkungan secara keseluruhan.

h. Pengungkapan biaya lingkungan akan meningkatkan nilai dari pemegang saham karena kepedulian perusahaan terhadap pelestarian lingkungan.

Menurut Niap (2006) dikutip dari Jurnal Santi Rahma Dewi, komponen - komponen biaya lingkungan terdiri dari biaya tersembunyi (hidden costs), biaya konvensional 
(conventional costs), biaya kontijensi (contingent costs), biaya citra (image and relationship costs), dan biaya eksternal (social costs or externalities). Pengorbanan biaya lingkungan yang dikeluarkan oleh pemilik usaha UMKM bukan hanya sekedar dinilai dengan satuan uang yang telah dikeluarkan ataupun belum dikeluarkan. Pengorbanan biaya lingkungan yang dimaksud lebih ke arah bagaimana UMKM dapat lebih peduli lingkungan sekitar dengan melakukan contoh riil yang ada.

\section{Kepedulian Lingkungan}

Menurut Sue (2003:43) kepedulian lingkungan menyatakan sikap - sikap umum terhadap kualitas lingkungan yang diwujudkan dalam kesediaan diri untuk menyatakan aksi aksi yang mendapat meningkatkan dan memelihara kualitas lingkungan dalam setiap perilaku yang berhubungan dengan lingkungan. Oleh karena kepedulian dinyatakan dengan aksi - aksi, maka seseorang yang peduli lingkungan tidak hanya pandai membuat karya tulis tentang lingkungan, tetapi hasil karya tulis itu ditunjukan dengan tindakan yang nyata.

Sikap kepedulian lingkungan ditunjukkan dengan adanya penghargaan terhadap alam. Pada hakikatnya penghargaan terhadap alam adalah kesadaran bahwa manusia menjadi bagian alam, sehingga mencintai alam juga mencintai kehidupan manusia (Suparno, 2008 dikutip dari Jurnal Santi Rahma Dewi).

Kemudian menurut Nenggala (2007:173) dikutip dari Jurnal Santi Rahma Dewi, indicator untuk seseorang yang peduli lingkungan dengan selalu menjaga lingkungan sekitar, tidak mengambil, menebang atau mencabut tumbuhan di sepanjang jalan, tidak mencorat coret pohon, batu jalan atau dinding, selalu membuang sampah di tempatnya, tidak membakar sampah di sekitar pemukiman, menimbun barag bekas, membersihkan sampah - sampah yang menyumbat saluran air.

\section{METODE PENELITIAN}

\section{Jenis Penelitian}

Penelitian ini merupakan sebuah penelitian Kualitatif Deskriptif dengan Studi Kasus yaitu metode yang dipergunakan dengan tujuan mempelajari sedalam - dalamnya salah satu gejala yang nyata dalam kehidupan bermasyarakat, dengan objek adalah keadaan kelompok kelompok dalam masyarakat, lembaga - lembaga masyarakt, maupun individu - individu dalam masyarakat (Sri W dan Sutapa Mulyana, 2007) dikutip dari Jurnal Santi Rahma Dewi.

Penelitian kualitatif adalah metode penelitian yang berlandaskan pada filsafat post positivisme, digunakan untuk meneliti pada kondisi objek yang alamiah, dimana peneliti adalah instrument kunci. Tujuan dari penelitian kualitatif sendiri adalah untuk menjelaskan suatu fenomena dengan sedalam - dalamnya dengan cara pengumpulan data yang sedalam dalamnya pula, yang menunjukkan pentingnya kedalaman dan detail suatu data yang diteliti. Penelitian deskriptif mempunyai arti penelitian yang berusaha mendiskripsikan suatu gejala, peristiwa, kejadian yang terjadi. Penelitian ini memusatkan perhatian pada masalah - masalah aktual sebagaimana adanya pada saat penelitian berlangsung. Tujuan dari penelitian deskriptif adalah untuk menyajikan gambaran lengkap mengenai setting sosial suatu fenomena dengan 
jalan mendeskripsikan sejumlah variabel yang berkenaan dengan masalah dan unit yang diteliti antara fenomena yang diuji.

\section{Lokasi Penelitian}

Lokasi penelitian merupakan tempat yang dijadikan objek penelitian oleh peneliti untuk mendapatkan data - data yang akurat yang bisa diteliti. Menurut Moleong (2007:132. Dikutip dari Jurnal Diana Puspitasari) cara terbaik untuk ditempuh dengan jalan mempertimbangkan teori subtantif dan menjajaki lapangan dan mencari kesesuaian dengan kenyataan yang ada di lapangan. Keterbatasan geografi dan praktis seperti waktu, biaya, tenaga perlu juga dijadikan pertimbangan dalam penentuan lokasi penelitian.

Lokasi penelitian sendiri merupakan tempat dimana penelitian akan dilakukan. Lokasi merupakan tahap penting yang dibutuhkan untuk penelitian kualitatif, karena ketika lokasi sudah ditetapkan maka objek dan tujuan sudah ditetapkan. Lokasi penelitian yang akan dibahas dalam penelitian ini berada di Pabrik Kecap Lele dari Kabupaten Pati, Jawa Tengah.

\section{Subyek Penelitian}

Subyek penelitian adalah hal, benda, orang dan tempat dimana data untuk variable penelitian melekat dan yang dipermasalahkan dalam penelitian (Arikunto, 2006:116). Subyek penelitian akan dinamakan narasumber, informan, partisipan dalam penelitian. Sugiyono (2013:298) menjelaskan bahwa pada umumnya dalam penelitian kualitatif tidak menggunakan populasi karena penelitian kualitatif berangkat dari kasus tertentu yang ada pada situasi sosial tertentu dan hasil kajiannya tidak akan diberlakukan ke populasi, tapi ditransferkan ke tempat lain pada situasi sosial yang memiliki kesamaan dengan situasi sosial kasus yang dipelajari.

\section{Jenis dan Sumber Data}

Jenis dan sumber data yang ditulis dalam penelitian ini adalah jenis data primer dengan data internal. Jenis data primer sendiri merupakan data yang dikumpulkan oleh individu atau perorangan atau suatu organisasi secara langsung dari objek yang diteliti dan untuk kepentingan studi yang bersangkutan yang dapat berupa interview dan observasi. Kemudian untuk sumber data di dapat dari narasumber internal sendiri dimana data tersebut diperoleh dari narasumber yang berperan sangat penting bagi peneliti karena narasumber adalah kunci utama bagi peneliti dalam memperoleh informasi. Dalam penelitian ini, data yang di dapat adalah data primer dari interview kepada pemilik Pabrik Kecap Lele dan observasi lapangan dan juga peneliti terjun langsung ke lapangan untuk melihat kondisi lapangan.

\section{Proses Penelitian}

Dalam suatu penelitian pasti ada alur atau proses penelitian yang akan dilalui orang peneliti guna mendapatkan data yang sesuai dengan apa yang diinginkan. Berikut adalah proses penelitian yang digunakan oleh peneliti untuk mendapatkan data - data :

1. Langkah awal adalah datang ke Pabrik Kecap Lele guna meminta ijin kepada pemilih usaha untuk melakukan penelitian dan wawancara di pabrik tersebut.

2. Ketika sudah disetujui, peneliti kemudian melakukan survei ke tempat limbah yang berada di ujung pabrik guna melihat dan mengambil gambar untuk dijadikan bukti pendamping dalam penelitian. 
3. Selanjutnya peneliti membuat paper untuk mencatat semua hal - hal penting yang sudah di dapatkan dari lapangan.

4. Kemudian masuk dalam tahap wawancara, peneliti melakukan pertemuan dengan pemilik pabrik untuk melakukan wawancara mengenai limbah dan penanganannya beserta biaya yang dikeluarkan oleh sang pemilik pabrik untuk membuat penampungan limbah tersebut.

5. Lalu peneliti membuat ringkasan atau kesimpulan dari wawancara yang didapatkan dari pemilik atau karyawan perusahaan yang diteliti. Pencatatan bisa dilakukan secara tertulis terlebih dahulu dan kemudian dituangkan dalam lembar ketikan.

\section{Teknik Pengumpulan Data}

Data dalam penelitian ini dikumpulkan dalam berbagai cara yang disesuaikan dengan informasi yang diinginkan (Arikunto, 2006:221), dilakukan dengan :

\section{Observasi}

Observasi merupakan metode pengumpulan data yang paling alamiah dan paling banyak digunakan. Secara umum observasi berarti pengamatan, penglihatan. Sedangkan secara khusus dalam dunia penelitian, observasi adalah mengamati dan mendengarkan dalam rangka memahami, mencari jawaban, mencari bukti terhadap fenomena sosial keagamaan selama beberapa waktu tanapa memengaruhi fenomena yang diobservasi, dengan mencatat, merekam, memotret fenomena tersebut sebagai bukti penemuan dan analisis.

2. Wawancara

Wawancara adalah percakapan yang dilakukan dengan maksud tertentu. Wawancara itu dilakukan oleh dua pihak yaitu pewawancara (interviewer) yang merupakan orang yang mengajukan pertanyaan dan yang diwawancarai (interviewee) yang merupakan orang yang menjawab pertanyaan tersebut.

3. Dokumentasi

Dokumentasi merupakan cara mengambil gambaran di lapangan yang akan dijadikan objek penelitian. Misalnya pengambilan video dan pengambilan gambar sebagi bukti asli.

\section{Informan}

Informan adalah orang yang memberikan informasi yang dibutuhkan oleh peneliti guna mendapatkan informasi atau data mengenai perusahaan yang diteliti secara detail dan disampaikan dengan baik kepada peneliti. Seseorang yang akan saya jadikan informan dalam riset saya ini adalah Pemilik Pabrik Kecap Lele, karyawan yang bertugas di bagian limbah, dan karyawan yang bertugas dibagian mengolah kecap.

\section{PEMBAHASAN}

Pabrik Kecap Lele berdiri sekitar tahun 1954, perusahaan ini hanya berupa sebuah toko kecil yang menjual bumbu masak dan kecap yang belum memiliki merek, dengan volume penjualan kecil. Dijual sendiri keliling kota dengan mengendarai sepedaoleh pemiliknya. Nama awalnya adalah Perusahaan Kecapcap "Ikan Lele Ny. Go Tjwan Hok" dan telah memiliki ijin dari Departemen Kesehatan Republik Indonesia pada tahun 1988 yaitu Nomor SP 18/11.24/88.Dengan perkembangan konsumen yang begitu pesat, dibutuhkan pabrik yang lebih luas dan longgar agar perusahaan dapat mengikuti kebutuhan konsumennya maka lokasi Perusahaan kecap "Ikan Lele" dipindahkan ke lokasi baru Jl. Raya Pati - Juwana Km. 3, Pati, 
Jawa Tengah.Ini disebabkan lokasi awal tempat produksi kecap sulit diperluas karena terletak di tengah kota.

Jumlah karyawan yang ada di Pabrik Kecap Lele sampai sekarang ini sekitar 50 - 60 orang karyawan yang dibagi dalam beberapa bidang. Untuk keselamatan kerja setiap karyawan diberikan sarung tangan dan masker. Pabrik Kecap Lele sendiri memberikan jamnian sosial berupa THR, BPJS, dan juga Tunjangan Tahunan untuk para karyawannya.

Pabrik Kecap Lele sendiri memiliki jam kerja 8 jam perhari. Mulai dari jam 8 pagi sampai jam 4 sore. Apabila ada lemburan, maka dimulai dari jam 4 sore sampai jam 8 malam. Untuk hari kerja mulai dari Hari Senin sampai Hari Sabtu.

Jenis - jenis kecap di Pabrik Kecap Lele sendiri ada beebrapa macam, yaitu : kecap yang dikemas di botol berukuran $600 \mathrm{ml}$; Kecap yang dikemas di dalam jerigen $7 \mathrm{~kg}$; Kecap yang dikemas di sachet atau plastik untuk isi ulang (refill) beraneka ukurannya, antara lain : $50 \mathrm{ml}, 340 \mathrm{ml}, 680 \mathrm{ml}$; Kecap yang dikemas seperti botol cuka berukuran $200 \mathrm{ml}$; Kecap yang dikemas dalam bentuk standing pot berukuran $600 \mathrm{ml}$.

Pemasaran di Pabrik Kecap Lele sendiri sudah tersebar di seluruh Kabupaten Pati, Rembang, Kudus - Semarang, Jepara, dan Salatiga.

\section{Hasil Penelitian}

\section{Mengenal Green Accounting}

Dari data informan yang diwawancarai oleh peneliti, karyawan dan pemimpin Pabrik Kecap Lele belum mengenal apa itu green accounting, Mengenal mengenai green accounting (akuntansi hijau) pemilik sendiri belum pernah mendengar. Karena pemilik sendiri kurang paham mengenai akuntansi hijau sendiri. Pemilik hanya paham paham bahwa limbah kecap jika masuk ke lingkungan tanpa diolah akan menyebabkan kerusakan lingkungan sekitar pabrik, untuk itu pemilik sudah memiliki bagian pengelolaan limbah yang bertugas mengolah dan menyaring limbah kecap agar layak masuk ke lingkungan sekitar pabrik, baik itu sungai ataupun parit sawah.

\section{Penerapan Green Accounting}

Untuk menjelaskan mengenai penerapangreen accounting di Pabrik Kecap Lele sendiri sudah dilaksanakan dengan baik dalam hal pengolahan limbah kecap agar tidak mengganggu ekosistem di sungai dan parit yang berada di kawasan pabrik kecap tersebut. di pabrik kecap memang sudah menerapkan green accounting sebagai dasar kepedulian lingkungan untuk daerah sekitar pabrik.

Untuk mendapatkan alat serta tempat penyaringan limbah yang baik dan layak, pemimpin perusahaan berusaha membangun dan mendatangkan alat yang baik digunakan dalam penyaringan limbah kecap tersebut. Maka dari itu tempat penyaringan limbah ini sudah direnovasi dan diperbaiki lebih baik dan lebih baik lagi, seperti yang sedang dilakukan para karyawan di tempat pengolahan limbah ketika peneliti datang. Mereka sedang memperbaiki alat dan mengecek pipa - piapa yang menjad tempat menyalurkan air limbah yang sudah disaring di penyaringan sebelumnya. Adanya perbaikan alat dan pipa tersebut bertujuan agar tidak ada kesalahan atau kerusakan dalam sistem pengoperasian alat penyaringan limbah 
tersebut yang mana jika terjadi kerusakan atau kesalahan dapat berkaibat fatal untuk lingkungan sekitar.

Penerapan mengenai green accounting di pabrik ini sudah terlihat jelas dilakukan dengan baik untuk menyelamatkan lingkungan sekitar pabrik agar tidak rusak dan ekosistem tetap berjalan dengan baik. Limbah yang dihasilkan dari penyaringan limbah kecap ini juga sudah diteliti oleh Dinas Kesehatan Kabupaten Pati, dimana air limbah yang sudah disaring benar - benar sudah layak untuk dilepas ke lingkungan bebas dan tidak mengganggu lingkungan hidup di daerah sekitar pabrik kecap.

Dari observasi yang telah peneliti lakukan, air yang dihasilkan dari pengolahan limbah tersebut memang sudah tidak berbau dan berwarna coklat jernih, tidak ada gumpalan gumpalan kecap atau kotoran lain yang dapat menyumbat atau mengganggu lingkungan. Untuk itu, di olahan limbah di rubik terakhir, air akan siap dialirkan ke sungai dan parit jika volume rubik sudah penuh agar bisa dialirkan lg air limbah yang sudah diolah di rubik sebelumnya.

\section{Pencatatan Kronologis Mengenai Green Cost}

Mengenai pencatatan di Pabrik Kecap Lele tersebut hanya ditanyakan oleh peneliti kepada pemimpin, karena pemimpin merupakan informan utama untuk diwawancarai mengenai manajemen perusahaan dan juga pencatatan pengeluaran dan pemasukan. Pemimpin di Pabrik Kecap Lele yang juga bertugas sebagai tim manajemen pabrik kecap. Pembayaran bahan baku dan apapun yang kurang yang ada di pabrik kecap tersebut langsung melewati pemimpin, tidak ada tim manajemen lain selain pemimpin pabrik kecap sendiri. Dikarenakan sudah dari dulu manajemen keuangan selalu dipegang pemilik dan pemimpin pabrik, karena pabrik ini merupakan milik keluarga.

Pencatatan mengenai pemasukan dan pengeluaran kas sendiri dilakukan secara manual namun tidak lengkap. Transaksi pencatatan terjadi jika bahan baku mulai menipis, juga mengenai pencatatan penjualan yang telah dilakukan dan mengenai gaji karyawan. Selain itu, untuk hal yang lain tidak dicatat oleh tim manajemen. Sama halnya seperti membangun tempat untuk pembuangan limbah atau penerapan green accounting, semua bahan dan peralatan tidak dicatat oleh tim manajemen pabrik. Karena sudah ada orang yang diberikan tanggung jawab untuk menyelesaikan pembuatan tempat penyaringan limbah tersebut. Pemimpin hanya menerima jadi untuk masalah limbah dan tidak mencatat berapa pengeluaran yang dihabiskan untuk membangun tempat, membeli peralatan penyaring limbah, bahan kimia untuk menetralkan bau limbah, dan juga biaya upah karyawan borongan yang ikut serta membangun tempat pengolahan dan penyaringan limbah tersebut.

Untuk masalah pengeluaran uang yang tidak dicatat oleh tim manajemen pabrik, berarti di Pabrik Kecap Lele sendiri belum mencatat secara kronologis green cost (biaya hijau)yang dikeluarkan untuk membuat tempat limbah dan menggaji karyawan borongan. Tidak ada bukti tertulis dari pemimpin dan pihak manajemen, kecuali nota yang sudah tercampur dengan nota nota yang lainnya.

Untuk itu, pada wawancara dengan pemimpin Pabrik Kecap Lele sendiri peneliti sudah memberikan saran secara langsung kepada pemimpin pabrik. Karena menurut peneliti apabila ada pencatatan secara khusus atau kronologis, maka pemimpin dan tim manajerial yang dilakukan oleh keluarga sendiri tidak akan kesusahan dalam mengecek keuangan dan juga 
mencegah terjadinya kecurangan yang bisa dilakukan oleh siapapun yang bekerja di pabrik. Selain itu, adanya pencatata itu juga bertujuan untuk melihat apakah terjadi kerugian atau keuntungan dan berapa besarnya akan terlihat, maka bisa dilihat mengenai keunggulan dan kelemahan produk kecap yang dibuat.

\section{Alur Pengolahan Limbah}

1. Air limbah kecap setelah pengolahan pemasakan kecap yang sudah dibuang ke tempat pembuangan limbah dialirkan ke kotak pertama penampungan limbah,

2. Lalu dialirkan ke 3 kotak yang menjadi satu dimana sudah ada penyaring berupa besi yang digunakan untuk menyaring bila mungkin ada plastik atau bahan yang bersifat padat lainnya. Terdiri dari penyaringan berukuran besar, sedang, dan kecil. Agar air bisa mengalir ke kotak berikutnya

3. Kemudian dialirkan ke pipa kedalam penyaringan ke 2 yang sudah terbebas dari benda padat, tapi bau masih menyengat dan juga masih sangat berwarna coklat susu kental serta berbui, karena disertai dengan sisa sisa endapan dari olahan kecapnya.

4. Kemudian dialirkan ke atas, ke tempat penyaringan bau limbah yang terdapat 3 buah tong besar berwarna biru yang berisi bakteri - bakteri pembunuh bau juga peralatan untuk mengalirkan bakterinya.

5. Limbah yang siap diberi bakteri pembunuh bau diendapkan terlebih dahulu agar bakteri bisa dituangkan dan bisa bekerja di penampungan berbentuk tabung. Jika tabung sudah penuh, maka akan mengalir ke tempat penyaringan berikutnya.

6. Air yang sudah diberi bakteri tadi akan dialirkan melalui pipa seperti air terjun ke bawah dan kemudian bui - bui bahan kimia akan terlihat itu berarti bahan kimia dari bakteri - bakteri tadi mulai bekerja.

7. Kemudian setelah penuh dan bisa melewati pipa, air limbah yang masih ada ampasnya akan di saring. Ampas tersebut akan diendapkan agar menjadi padat dan kemudian di ambil dan di letkkan di karung untuk dibuang di tempat pembuangan akhir.

8. Kemudian air yang sudah bebas dari ampasnya di alirkan ke 5 kotak yang ditutupi oleh beton di atasnya, penyaringan ini menyaring sisa - sisa bahan kimia yang kemudian akan dialirkan lagi melewati pipa pipa kecil.

9. Di kotak penyaringan ini, akan disaring lagi untuk dipastikan agar tidak mempunyai ampas lagi dan benar - benar cair dan bau sudah tidak ada.

10. Setelah itu akan dialirkan lagi ke kotak yang menjadi proses terakhir sebelum dialirkan ke kotak terakhir untuk dialirkan ke sungai dan paarit.

11. Yang terakhir dimana air dari limbah tersebut memang benar - benar sudah bebas dari bau juga ampas yang berbahaya bagi lingkungan sekitar, di ditampung pada penampungan paling akhir.

\section{PENUTUP}

\section{Kesimpulan}

Berdasarkan hasil pembahasan penelitian mengenai Pemahaman dan Kepedulian Dalam Penerapan Green Accounting pada Pabrik Kecap Lele di Kabupaten Pati dapat diambil beberapa kesimpulan : (1) Pabrik Kecap Lele kebanyakan belum mengerti apa itu green accounting (akuntansi hijau). Mereka hanya mengetahui tentang kepedulian lingkungan agar 
tidak mencemari lingkungan; (2) Pabrik Kecap Lele sudah menerapkan green accounting dengan membangun tempat penampungan dan penyaringan limbah. Agar air limbah yang dikeluarkan dari pabrik tidak merusak lingkungan sekitar pabrik; (3) Di Pabrik Kecap Lele sendiri belum ada pencatatan secara kronologis mengenai green cost. Karena dari pihak pemimpin dan manajemen sendiri tidak pernah mencatat pemasukan dan pengeluaran uang dan bahan baku.

\section{Saran}

Berdasarkan hasil dan kesimpulan dari penelitian mengenai Pemahaman dan Kepedulian dalam Penerapan Green Accounting pada Pabrik Kecap Lele di Kabupaten Pati, sebaiknya Pabrik Kecap Lele menerapkan pencatatan secara kronologis agar (1) Dapat mengetahui berapa kerugian dan keuntungan yang di dapatkan setiap bulan dan tahunnya secara pasti; (2) Bisa dijadikan acuan yang pasti untuk meningkatkan produktivitas dalam pembuatan kecap lele; (3) Tidak terjadi kecurangan oleh siapapun yang bekerja di pabrik; (4) Dapat mengetahui kelemahan dan keunggulan dari hasil produksi.

\section{DAFTAR PUSTAKA}

Astiti, Widhiyanti. (2014). Implementasi Green Accounting Berbasis University Social Responsibility (USR) Di Universitas Negeri Yogyakarta. Jurnal Nominal Volume III Nomor 2, 134 - 149.

Dewi, Santi Rahma. (2016). Pemahaman dan Kepedulian Penerapan Green Accounting : Studi Kasus UKM Tahu Sidoarjo. Prodi Akuntansi Fakultas Ekonomi \& Bisnis Universitas Muhammadiyah Sidoarjo.

Diana Puspitasari, SE, MM. (2018). Pemahaman Dan Kepedulian Dalam PenerapanGreen Accounting Pada UKM Tempe Di Kelurahan Krobokan, Kecamatan Semarang Barat. University Research Colloquium, 30 - 42.

H. Saputro, L. D. Mahfudz, dan T. A. Sarjana. (2018). Pengaruh Penggunaan Ampas Kecap dalam Ransum terhadap Isoflavon LDL dan HDL Telur Itik Mojosari. Jurnal Sain Peternakan Indonesia, Volume 13 Nomor 3, 238 - 243.

Kusumaningtias, Rohmawati. (2013). Green Accounting, Mengapa Dan Bagaimana?. ISBN, $137-149$.

Pentiana, Destia. (2019). Pemahaman dan Kepedulian Penerapan Green Accounting: Studi Kasus UKM Tahu Tempe di Kota Bandar Lampung.Jurnal Ilmiah ESAI Volume 13, No. 1, 38 - 50 .

Susilo, Joko. (2008). Green Accounting Di Daerah Istimewa Yogyakarta: Studi Kasus Antara Kabupaten Sleman Dan Kabupaten Bantul.JAAI Volume 12 No. 2, 149 - 162.

Utama, Anak Agung Gede Satia. (2016). Akuntansi Lingkungan Sebagai Suatu Sistem Informasi: Studi Pada Perusahaan Gas Negara (PGN).Jurnal Bisnis dan Manajemen, Volume 6 (1), 89 - 100. 
Zulhaimi, Hanifa. (2015). Pengaruh PenerapanGreen Accounting Terhadap Kinerja Perusahaan.Jurnal Riset Akuntansi Dan Keuangan, 3 (1), 603-616. 